\title{
ГЛАСНИК
}

АДВОКА Т КЕ КОМОРЕ ВО ВОДИН Е ЧАСОПИС ЗА ПРАВНУ ТЕОРИЈУ И ПРАКСУ

Година LXVIII

Новн Сад, септембар 1996

Књига 56

Бpoj 9

ч ЛАНЦИ

УДК 342.828

Др маријана Пајванчић

професор Правног факултета у Новом Саду

\section{ИЗБОРНЕ ЈЕДИНИЦЕ*}

САЖЕТАК: Прилог се бави једним од најтежих изборних проблема. Проблем је постављање граннца изборних јединица, и попуном више места посланичких у изборним јединицама. Резултат избора у униноминалним изборним јединицама не зависи само од воље бирача, веh такоБе и од неприхватљивог прошнривања гранища при успостављању изб́орних јединица. Могуһа су и екстремна одступања постављањем граница између већег броја изборних јединица. Ако има више партија, а избор се врши релативном већином, могућа екстремна одступања се увеһавају.

Кључне речи: изборна јединица, екстремна одступања, границе изборних јединица, релативна веКнна.

Конституисање представничког тела почива, у основи на два, подједнако значајна принципа. Први је принцип одлучивања (начело већине), а други принцип представљања према учешћу односно уделу (начело пропорционалности). У низу изборних система предност се даје принципу одлучивања, када се изборни систем јавља у једној од форми већинског изборног система. У другима је прихваћен принцип представљања и тада се изборни систем јавља у неком од облика пропорционалног изборног система. Трећој групи припадају изборни системи који у подједнакој мери уважавају оба принципа

- Рад примљен: 17. VII 1996. 
конститунсања представничког тела и тада су у питању различити облици мешовитих изборних система.

Прнхватање одреБеног принципа на коме се заснива конститунсање представничког тела операцнонализује се уз помоһ два основна инструмента:

Први је критеријум за освајање односно расподелу мандата. Овај критеријум операционализује се у низу различитих метода који се примењују на израчунавање основних параметара за освајање односно расподелу мандата (највећин број, изнадполовична већина, систем изборних квота, д'Онтова метода, метода по Харе-Нимајеру и др.).

Други је образовање изборних јединица.

Поред опредељивања за један од основна два принципа конститунсања представничког тела (начело већине односно начело представљања, или њихова комбинација), који у основи одреБују и тип изборног система, формирање изборних јединица је подједнако важно питање изборног система. Утицај који обликовање изборних јединица нма на тип изборног система је велик те се изборном географијом један тип изборног система може променити у други, а један принцип образовања представничког тела (на пример начело представљања) попримити облик другог принципа (начело већине). То је разлог што Ће Дитрих Нолен за изборну географију рећ̆и да она „не припада узалуд политички најспорнијим питањима у изради и оцени изборног система”, јер „за изборне шансе политичких странака има највеће значење"1.

У овом прилогу биће ближе осветљена питања од значаја за образовање изборних јединица и размотрен утицај који формирање изборннх јединица има на тип изборног система.

\section{1. ШТА ЈЕ ИЗБОРНА ЈЕДИНИЩА}

Појам избоорне јединице одреБују следећи елементн: број посланика који се бира у нзборној јединици; величнна бирачког тела које обухвата изборна једнница, територнјално простирање изборне јединице. Сва ова три елемента кумулативно одреБују појам изборне јединице. Свакој изборној јединици припада одреБени број посланичких мандата. Свака изборна јединица обухвата одређени део бирачког тела. Најзад, свака изборна јединица простире се на одреБ̄eном тернторијалном подручју.

Подручје изборних јединица одреbује се законима који уреБују материју избора. Најчешће су то посебни закони о изборним јединицама. Уколико је изборно законодавство кодификовано тада се и материја изборних јединица обухвата једним јединственим законом којн уреБуује изборе.

1 Д. Нолен: Нзборно ираво и сйранащки сустиав, Загреб, 1992, стр. 47. 


\section{2. ОСНОВНИ КРИТЕРИЈУМИ ОБРАЗОВАҢА ИЗБОРНИХ ЈЕДИНИЦА}

Основно мерило које се примењује на образовање изборних јединица је ослоњено на начело једнакости граьана у остваривању бирачког права, начело један човек - један глас. Поред овог основног критеријума, приликом образовања изборних јединица узимају се у обзир и други, не мање важни чиниоци: демографски, регионални, историјски, географски, економски, државно уреьење, територијална организација и др. Несумњиво да постизање оптималне усклаБености ових, по многим својствима разнородних чинилаца, налаже брижљив однос законодавца према послу који му је стављен у задатак - да обликује изборне јединице које ће оптимално изразити и ускладити различите критеријуме значајне за формирање изборних јединица.

Како су критеријуми о којима законодавац мора водити рачуна приликом формирања изборних јединица веома важно и изразито осетљиво конституционално питање, то су у неким уставним системима ови критеријуми утврБени у самом уставу. Законодавац тада није у прилици да сам установљава критеријуме за образовање изборних јединица, јер су они утврЂени у уставу, већ је његова надлежност ограничена на конкретизацију и примену уставом утврБених критеријума. Компаративна искуства изборних система показују да је ипак чешће заступљено и право законодавца да сам успоставља и утврђује критеријуме за образовање изборних једнница.

\section{3. ТИП ИЗБОРНЕ ЈЕДИНИЦЕ}

Основни критеријум разликовања изборних јединица је број посланика који се бира у изборној јединици. С обзиром на овај критеријум разликују се два основна типа изборних јединица: изборне јединице у којима се бира један посланик (униноминалне изборне јединице) и изборне јединице у којима се бира више посланика (плуриноминалне изборне јединице).

\section{а) Униноминалне изборне јединице}

Униноминалне изборне јединице су мале изборне јединице. У њима се бира само један посланик. Избор посланика у оваквој изборној јединици може се заснивати само на начелу већине (апсолугне нли релативне). Отуда, прихватање некога од већ̆инских типова изборног система, прати истовремено и образовање униноминалних изборних јединица.

Униноминална изборна јединица увек обухвата одрећени део бирачког тела. При томе у уставним системима се применују два мерила према којима се дефинише бирачко тело: 
- Прво, у пракси изборних система често прихваћено мерило, узима у обзир број становника на подручју на коме се образује изборна јединица. У том случају изборна јединица обухвата и оне становнике одреБеног подручја који располажу бирачким правом и оне који овим правом не располажу. У овим се изборним јединицама један посланик бира на одреБени број становника².

- Друго, у пракси изоборних система ређе прихваћено мерилоз, узимају у обзир број бирача (лица која располажу бирачким правом) приликом формирања изборне јединице. Један посланик се у овом случају бира на одређени број бирача.

\section{б) Плуриноминалне изборне јединице}

Плуриноминалне изборне јединице су оне изборне јединице у којима се бира више од једног посланика. Плуриноминалне изборне јединице се могу образовати како у изборним системима који почивају на начелу веһине, тако и у онима који почивају на начелу представљања. У овим последњим плуриноминалне изборне јединице су правило.

Образовање плуриноминалних изборних јединица знатно је сложеније од образовања униноминалних изборних јединица. Плуриноминалне изборне јединице, поред осталих критеријума за образовање изборних јединица морају истовремено задовољити два подједнако важна критеријума: један глас).

- Најпре принцип једнакости бирачког права (један човек -

- Истовремено и принцип сразмерности представљања, оптимално изражавајући и осигуравајући начело сразмерности представљања (постизање што вишег индекса пропорционалности).

За плуриноминалне изборне јединице карактеристично је да се границе ових изборних јединица не мењају. Оне се често обликују у складу са одређеном територијалном организацијом или пак са организацијом судства. Отуда се нужна усклаБивања која су условљена демографским и другим променама, у овим изборним јединицама врше променом броја посланика који се бира у изборној јединици. У зависности од тога да ли је бирачко тело у изборној јединици смањено или повећано, смањује се или повећава број посланика који се бира у изборној јединици.

Територијално простирање птуриноминалних изборних јединица, како је већ̆ изнето, често се подудара са одговарајућим подручјем територијалне организације (управне, судске и др.). То, надаље, доводи до неједнаке величине изборних јединица у оквиру истог типа

2 На пример у уставном систему Југославије.

3 На пример у уставном систему Португалије. 
изборног система у истој држави, као и до одређених диспропорција које су последица регионалне територијалне поделе, а посебно оних које су везане уз подручја са изразитом концентрацијом бнрачког тела (градови) односно дисперзије (сеоска подручја).

За плуриноминалне изборне јединице често је карактеристично да се границе ових изборних јединица не мењају, а да се нужна усклаБивања која су условљена променама демографских и других фактора од значаја за обликовање изборних јединица, врше променом броја посланика који се бира у изборној јединици. Број посланика који се бира у плуриноминалној изборној јединици се смањује или повећава, у зависности од смањивања или повећавања броја становника (бирача) у изборној јединици.

Најзад, птуриноминалне изборне јединице се обликују тако да се територијално простирање ових изборних јединица често подудара са подручјем одреБене територијалне организације управне или судске власти. То, надаље, доводи до неједнаке величине изборних јединица у истој држави и у оквиру истог изборног система ${ }^{4}$, као и до одреБених диспропорција које су последица регионалне поделе, а посебно до проблема на релацији концентрација (урбана подручја) односно дисперзија (рурална подручја) бирачког тела.

\section{4. ОГЛЕД О ПОСТАВЉАҢУ ГРАНИЦА ИЗБОРНИМ ЈЕДИНИЦАМА}

Следећи пример илуструје постављање граница изборним јединицама.

Први случај показује почетну претпостављену вољу бирача и четири могуће поделе једног подручја на изборне јединице обједињавањем појединих делова тога подручја (границе изборних јединица).

Други случај илуструје минималну промену бирачке воље изражену у четири од могућих дванаест подручја на којнма се изборне јединице обликују, ако која у крајњем исходу може дати изборни резултат потпуно супротан од изборног резултата који даје првобитна подела изборних јединица (утицај минималне промене бирачке воље на изборни резултат).

\section{Почетна претпостављена воља бирача}

\begin{tabular}{|l|l|l|l|l|l|}
\hline $\mathrm{AAB}$ & $\mathrm{ABB}$ & $\mathrm{AAB}$ & $\mathrm{ABB}$ & $\mathrm{ABB}$ & $\mathrm{AAA}$ \\
\hline $\mathrm{ABB}$ & $\mathrm{ABB}$ & $\mathrm{AAA}$ & $\mathrm{BBB}$ & $\mathrm{AAA}$ & $\mathrm{AAB}$ \\
\hline
\end{tabular}

4 Компаратнвна искуства показују у том погледу илустративне примере. Тако се распони у величини изборних јединица крећу од 1-55 (Португалија, Италија); 2-70 (Аргентина); 1-33 (ШПпанија); 1-37 (Венецуела) и сл. Цитирано према Д. Нолен, ор. cit., стр. $51,54$. 
I подела $\mathrm{B}=3 \mathrm{~A}=1$

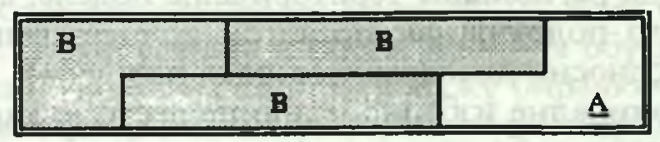

II подела $\mathrm{B}=2 \mathrm{~A}=2$

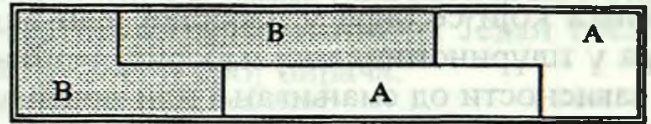

III подела $\mathrm{B}=1 \mathrm{~A}=3$

\begin{tabular}{|l|l|l|}
\hline $\mathbf{A}$ & & \\
\hline $\mathbf{A}$ & $\mathbf{B}$ & \\
\hline
\end{tabular}

IV подела $\mathrm{B}=0 \mathrm{~A}=4$

\begin{tabular}{|l|l|}
\hline $\mathbf{A}$ & $\mathbf{A}$ \\
\hline $\mathbf{A}$ & $\mathbf{A}$ \\
\hline
\end{tabular}

Промена бирачке воље у четири од дванаест делова који чине подручје изборних јединица

\begin{tabular}{|l|l|l|l|l|l|}
\hline $\mathrm{ABB}$ & $\mathrm{ABB}$ & $\mathrm{AAB}$ & $\mathrm{ABB}$ & $\mathrm{ABB}$ & $\mathrm{AAB}$ \\
\hline $\mathrm{BBB}$ & $\mathrm{ABB}$ & $\mathrm{AAA}$ & $\mathrm{BBB}$ & $\mathrm{AAA}$ & $\mathrm{ABB}$ \\
\hline
\end{tabular}

I подела идентична: $\mathrm{B}=3 \mathrm{~A}=1$

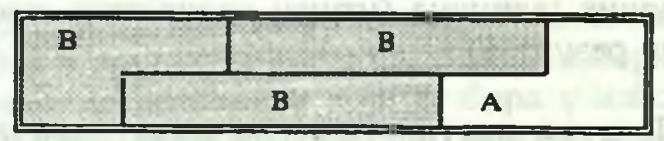

IV подела супротна: $\mathrm{B}=4 \mathrm{~A}=0$

\begin{tabular}{|c|c|c|}
\hline $\mathrm{B}$ & $\mathrm{B}$ \\
\hline $\mathrm{B}$ & $\mathrm{B}$ \\
\hline
\end{tabular}

Општи обрасци које приказују претходни примери, као и ефекти које имају границе постављене у изборним јединицама на изборни 
резултат вишеструко се увеһавају уколико се повеһа број изборних јединица на истом подручју, или се пак повећа број политичких групација које суделују у изборној утакмици.

Повећавање броја изборних јединица:

Уколико се на истом подручју повећа број изборних јединица могућност да се успостављањем граница изборних јединица одступи од стварне воље бирачког тела се увеһава. Изгледи да у оваквим случајевима настану екстремна одступања измеБу стварне воље бирачког тела и резултата избора су знатно већи.

Следећи примери илуструју изразита одступања измеБу воље бирачког тела и резултата избора, до којих долази услед повећавања броја изборних јединица.

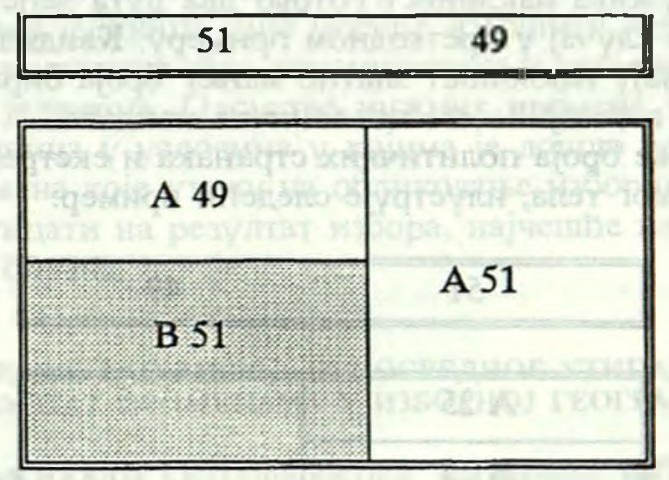

Кандидати странке В уживају подршку преко половине бирача (51\%) у преко половине укупног броја изборних јединица (51\%). Кандидатима странке В припашће преко половина укупног броја посланичких мандата. Кандидати странке A, меБутим, уживају подршку већине бирача (51\%) у мање од половине изборних једнница (49\%), као и подршку мање од половине бирача (49\%) у већини изборних јединица (51\%). Кандидатима странке В припашће преко половине посланичких мандата, иако њени кандидати уживају подршку $26 \%$ бирачког тела, а кандидатима странке А припашће мање од половине посланичких мандата иако у укупној бирачкој популацији кандидате ове стране преферира чак $74 \%$ бирачког тела. Иако ужива наклоност само нешто више од четвртине укупног бирачког тела странка Б односи победу на изборима, док странка А, премда ужива подршку готово три четвртине бирачког тела, остаје у парламенту у мањини.

Претпоставимо да кандидати странке В, уживају подршку мање од половине бирача (49\%) у свим изборним јединицама, док кандидати странке А уживају наклоност више од половине бирачког тела (51\%) у свим изборним јединицама. У овом примеру кандидати странке В уживају подршку готово два пута више укупног броја бирача (49\%) него у претходном примеру (26\%), а странка остаје без 
иједног посланичког мандата. Странка В у овом случају не само да није победник изборне утакмице, већ не осваја ниједан посланички

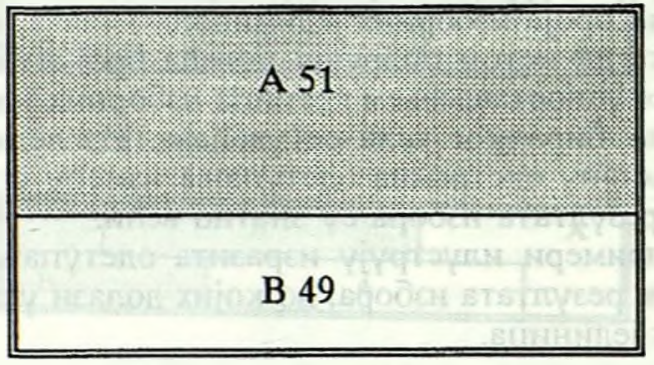

мандат, мада ужива наклоност готово два пута већег броја бирача него што је то случај у претходном примеру. Кандидати странке А, меБутим, уживају наклоност знатно мањег броја бирача (51\% у односу на $74 \%$ ), а освојиће све посланичке мандате.

Повећавање броја политичких странака и екстремна одступања од вољь бирачког тела, илуструје следећи прнмер:

\begin{tabular}{|c|c|}
\hline 51 & 49 \\
\hline A 25 & \multirow[b]{3}{*}{ A B C } \\
\hline B 25 & \\
\hline C 24 & \\
\hline D 26 & \\
\hline
\end{tabular}

У овом случају странка D чији кандидати уживају наклоност приближно једне четвртине бирачког тела у преко половине укупног броја изборних јединица $(51 \%)$ освојиће већину посланичких мандата у представничком телу.

\section{5. УТИЦАЈ ОБРАЗОВАЪА ИЗБОРНИХ ЈЕДИНИЦА НА РЕЗУЛТАТ ИЗБОРА}

Образовање изборних јединица утиче и на резултат избора. Према Д. Нолену постоје два основна начина који изражавају утицај обликовања изборних јединица на резултат избора.

Први начнн се огледа у активном и непосредном утицају, када се обликовањем изборних јединища настоји обезбедити предоминација или предност у изборној јединици за одреБене политичке 
странке. Постоји више могуһих облика у којима се то манифестује, меБу којима су два карактеристична:

- Формирање изборних јединица утврьења (бункера) које почивају на концентрацији бирачког тела наклоњеног одрењеном кандидату или политичкој странци. Овакво обликовање изборне јединице придоноси освајању посланичког мандата.

- Образовање изборних јединица успостављањем таквих граница измеbу њих које цепају бирачко тело наклоњено одређеном кандидату или странци. Тзв. ефекат границе која доводи до сударања (одбијања) и поделе бирачког тела које преферира одређеног кандидата или политичку групацију умањује изгледе на освајање посланичког мандата.

Други начин се испољава пасивно и карактерише га одсуство нужних интервенција и неопходних реформи изборних јединица. Поделу на изборне јединице није могуће извршити једном за унапред дужи временски период због динамичности и промена у конципирању изборних јединица. Одсуство нужних промена у конципирању изборних јединица у условима у којима је дошло до демографских и других промена које утичу на обликовање изборних јединица, такође може утицати на резултат избора, најчешће неједнакошһу изборног права бирача.

\section{GERRYMANDERING КАO METОД НЕПОСРЕДНОГ УТИЦАЈА НА ИЗБОРНИ РЕЗУЛТАТ ПРОМЕНАМА У ИЗБОРНОЈ ГЕОГРАФИЈИ}

Y теорији избора Gerrymanderings (стварање изборних јединица утврБења које осигуравају освајање мандата односно постављањем граница изборних јединица отежава освајање посланичког мандата) ${ }^{6}$ често се наводи као типичан пример политички пристрасне поделе на изборне јединице.

Изборне јединице се формирају водећи рачуна о концентрацији (односно о дисперзији) бирача наклоњених одреБеном кандидату. Стварањем оваквих изборних јединица на изборни резултат се може утицати, у основи, на два начина:

Први се манифестује таквим обликовањем граница изборних јединица које ће максимално обухватити бирачко тело наклоњено одреБеном кандидату, односно политичкој странци. На обликовање ових изборних јединица примењен је принцип концентрације бирачког тела које преферира одређеног кандидата или политичку странку. У овако обликованој изборној јединици кандидат (странка) који

5 Назив потиче из изборне праксе САД и обликовања једне изо̄орне јединице за извесног господина Џерија, а која је внзуелно лодсеһала на саламандер. Отуда је настала кованица Gerrymandering.

${ }^{6}$ Касније је овај израз добио шире значење обухватајући не само изб̄орне јединице бункере, већ и сваки други вид политички пристрасне поделе на изборне јединище. 
ужива популарност меБу одређеним бирачима има изгледа на сигурну изборну победу само ако је бирачко тело концентрисано у изборној јединици. У противном његови изгледи на изборни успех су минимални. Овакве изборне јединице називају се и изборним јединицама утврБењима (бункерима). јединица:

Првобитне границе изборних јединица

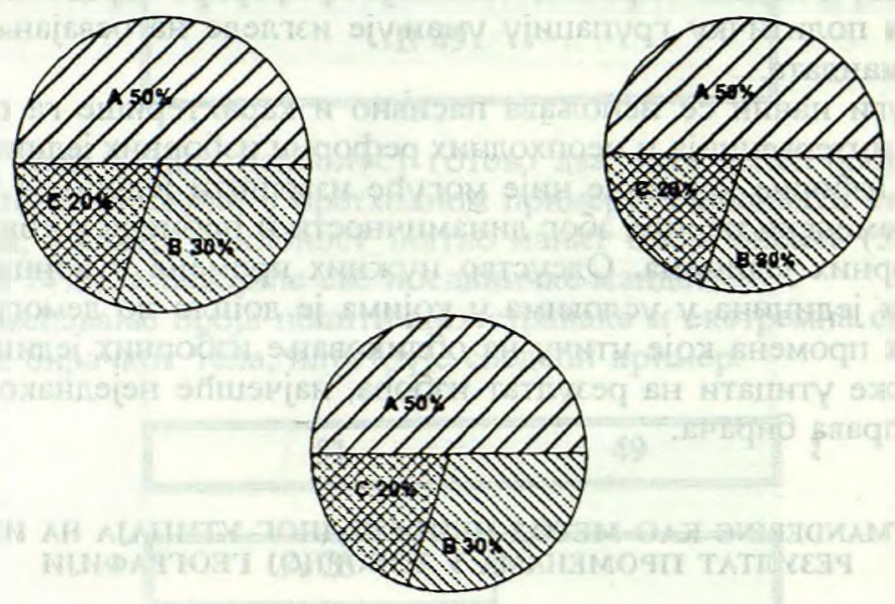

Мандат у све три изборне једннице осваја кандидат странке A, док кандидат странке $\mathrm{C}$ нема никаквих изгледа да освоји мандат при оваквом постављању граница изборних јединица.

Нове границе изборних јединица на истој популацији бирача

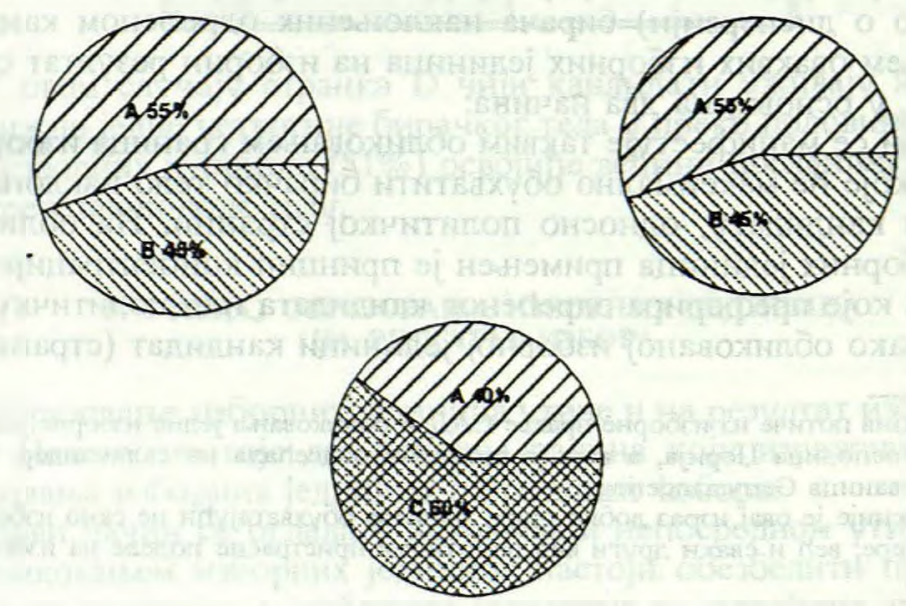


У новој подели исте бирачке популачије на три изборне јединице, бирачко тело које је наклоњено кандидату странке $C$, концентрисано је у трећ̆ој изборној једнници (изборна јединица бункер - утврБење), у којој овај кандидат осваја мандат. Новнм обликовањем граница измеБу изборних јединица, мандат у изборним јединицама 1 и 2 припашhе кандидату странке А који у укупном бирачком телу ужива подршку преко половине бирача. Кандидат странке В неһе бити изабран иако у укупном бирачком телу ужива подршку приближно једне трећине бирача. Кандидат странке C освојиће мандат у једној изборној јединици иако у укупном бирачком телу ужива подршку свега једне петине бирача.

Други начин обликовања изборних јединица почива на дисперзији (расцепканости) и подели бирачког тела. Обликовањем граница изборне јединице бирачко тело које преферира одрењеног кандидата се цепа између више изборних јединица. На тај се начин постиже неутрализација изборног потенцијала тога кандидата што за последицу има губитак на изборима.

Следећи пример илуструје овакво постављање граница измеБу изборних јединица:

\section{Првобитне границе изборних јединича}
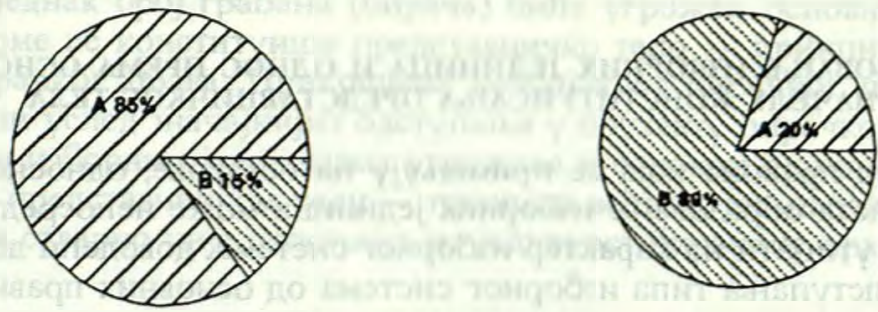

Y овом случају у првој изборној јединици мандат he освојити кандидат странке А ( $85 \%$ бирача у овој изборној јединици гласало je за кандидата A), док he у другој мандат припасти кандидату странке В (80\% бирача гласало је за кандидата В).

Нова подела на изборне јединице поставила је границе изборних јединица распореБујућ̆и бирачки потенцијал кандидата странке В у две изборне јединице тако да у свакој од изборних јединица понаособ не прелази половину. Изборни резултат ће у том случају бити освајање оба мандата од стране кандидата странке А. У овом случају изборни потенцијал странке А боље је распоређен у изборним јединицама, а при том је неутралисан изборни потенцијал странке В. 


\section{Нове границе изборних јединица идентичном бирачком телу}
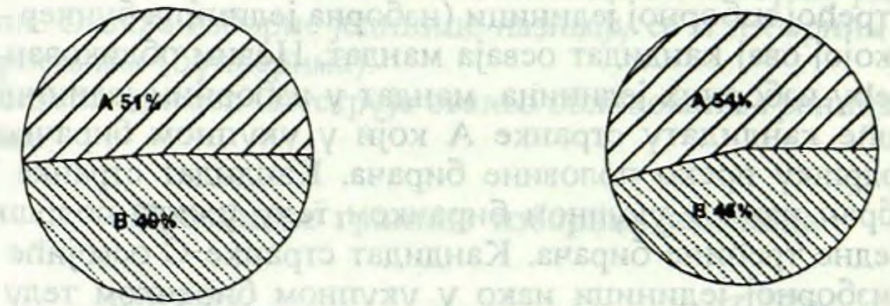

Овај пример илуструје и проблем тзв. „бачених гласова”. „Баченим гласовима" У униноминалним изборним јединицама назнвају се сви они гласови преко 50\% које освоји кандидат странке фаворита изборне утакмице. У изборним јединицама у којима се бира само један кандидат ови гласови не придоносе освајању посланичког места, јер је за освајање посланичког места довољно преко половине гласова. Сви гласови освојени преко тог броја су сувишни у конкретној изборној јединици, јер не лридоносе освајању мандата. Али, ови гласови могу одлучујуће допринети освајању мандата у некој лругој изборној јединици, у којој кандидати странке фаворита не ужнвају довољну популарност.

\section{7. ОБРАЗОВАНЕ ИЗБОРНИХ ЈЕДИНИЦА И ОДНОС ПРЕМА ОСНОВНОМ НАЧЕЛУ КОНСТИТУИСАҢА ПРЕДСТАВНИЧКОГ ТЕЛА}

Поред правила која се примењују на освајање, односно расподелу мандата образовање изборних јединица може непосредно, па и пресудно утицати на карактер изборног система, доводећи до промене, или одступања типа изборног система од основних правила примењених на конститунсање представничког тела.

Облик у коме се то испољава различит је када су у питању униноминалне, односно плуриномнналне изборне јединице.

\section{а) Униноминалне изборне јединице}

У изборним системима који почивају на већинском принципу за обликовање изборних јединица (униномнналне изборне једннице) од посебне је важности таква подела бирачког тела нзмеБу изборних јединица у којој Һе свака од изб́орних јединица обухватити подједнаке делове бирачког тела. Репрезентовање грађана у парламенту у изборним системима који већински принцип узимају као темељни принцип обликовања представничког тела, је легитимно само ако почива на начелу један човек један глас, дакле, ако уважава принцип једнакости грађана у остваривању бирачког права, и на то ослоњен принцип већине као основ представљања и одлучивања. Подједнак 
обухват бирача у свакој изборној јединици је претпоставка да he сваки глас бирача имати једнаку вредност и обезбеБује једнакост бирачког права.

Beha одступања у погледу броја бирача обухваһених подручјем изборних јединица воде прикривеној неједнакости бирачког права, јер се један посланик бира на неједнак број граһана (бирача). Ако изборне јединице обухватају неједнак број (грађана) бирача, а у свакој изборној јединици се бира један посланик, тада ие у једној изборној јединици за избор посланика бити потребан мањи број гласова, а у другој већи. Бирачи hе у том случају бити у неједнаком положају, бирачко право неће бити једнако јер не уважава правило један човек - један глас.

Следећи пример ово илуструје:

Изборна јединица I 10.000 грађана - бира се један посланик Изборна јединица II 20.000 грађана - бира се један посланик

Вредност гласова у првој у поређењу са другом изборном јединицом је $1: 2$, што значи да један глас дат у првој изборној јединици вреди као два гласа дата у другој изборној јединици.

Ако, дакле, у униноминалним изборним јединицама, границе изборних јединица буду постављене тако да изборне јединице обухватају неједнак број грађана (бирача) биће угрожен основни принцип на коме се конституише представничко тело - принцип једнакости бирачког права. Прикривена неједнакост бирачког права до које долази услед значајнијих одступања у обухвату бирачког тела у појединим изборним јединицама угрожава и основни принцип одлучивања у представничком телу - принцип већине, јер парламентарна већина стварно није ослоњена на једнакост бирачког права.

\section{б) Плуриноминалне изборне јединице}

Пресудно питање приликом образовања плуриноминалних изборних јединица је број посланика који се бира у једној изборној јединици. Овај број у подједнакој мери изражава два принцила конституисања представничког тела: начело једнакости бирачког права и начело сразмерности представљања.

С обзиром на могућност испуњавања ова два подједнако значајна начела, у литератури која обраБује изборну проблематику, плуриноминалне изборне јединице се групишу у три подгрупе. Према Д. Нолену ове подгрупе су:

- Мале изборне јединице. То су оне плуриноминалне изборне јединице у којима се бира два до пет посланика.

- Средње изборне јединице. У овој су групи оне плуриноминалне изборне јединице у којима се бира од шест до десет посланика. 
- Велике изборне јединице. Ова подгрупа обухвата изборне јединице у којима се бира преко десет посланика.

Учинак сразмерности (тзв. индекс пропорционалности) непосредно је повезан са типом изборне јединице. У малим изборним јединицама индекс пропорционалности је низак, а у великим изборним јединицама висок. Поред тога процентуална препрека гласова неопходних за освајање мандата у малим изборним јединицама је висока, док је у великим изборним јединицама ниска.

Следећа табела илуструје однос величине изборне јединице, процентуалну препреку за освајање мандата и индекс пропорционалности:

\begin{tabular}{ccc}
\hline велкчина изборне јединице & процентуална препрека & индекс пропорционалности \\
\hline мала & висока & низак \\
средња & средња & средњи \\
велика & ниска & висок \\
\hline
\end{tabular}

Изборни систем који почива на начелу пропорционалности и на расподелу мандата примењује неки од критеријума пропорционалне расподеле мандата, уколико се реализује у малим плуриноминалним изборним јединицама даһе изборни резултат који даје примена изборног система заснованог на веһинском принципу (у облику релативне већине).

Тако, на пример у плуриноминалној изборној јединици са три мандата шансе за освајање мандата имаће странка која освоји најмање $18 \%$ гласова, а реалне изгледе на заступљеност у представничком телу имаће три странке'. Када би једној изборној јединици припало девет мандата (изборна јединица средње величине) и странка са мање од $9 \%$ гласова имала би изгледа да суделује у расподели мандата и буде заступљена у представничком телу. Индекс пропорционалности је у првом случају низак, док је у другом средњи.

Велике плуриноминалне изборне јединице, дакле, олакшавају освајање мандата и увећавају изгледе да и мање политичке странке буду заступљене у парламенту, јер умањују проценат гласова које је потребно освојити како би се суделовало у расподели мандата.

Променама у величини изборних јединица, посебно изборном географијом која почива на малим плуриноминалним изборним јединицама могуће је, не мењајућ̆и основна правила која пресуьују у расподели мандата изменити природу изборног система преображавајућии пропорционални изборни систем (с обзиром на резултат избора) у већински изборни систем.

Из изнетог следи да се начело пропорционалности у конституисању представничког тела у подједнакој мери обезбеБује са једне стране методом расподеле мандата (метод прерачунавања гласова), а

7 Ово може илустровати изборни систем примењен у Ирској. 
са друге стране величином плуриноминалних изборних јединица (изборна географија). Сагласна и складна примена оба наведена инструмента обезбеБује да у пропорционалном изборном систему не буде угрожено основно начело конституисања представничког тела.

\section{CONSTITUENCIES}

\section{Dr Marijana Pajvancic}

Sum mary

The article deals with one of the most difficult electoral problems. The problem is the location of constituency boundaries, and the filling many places in single-place constituencies. The result of an election in single-place constituencies is effected not only by the opinions of the voters, but also by an unacceptable extend in the location of constituency boundaries. The possible extremes of distortion is due to boundaries between a large number of constituencies. If there are more than two parties and election is by relative majority, the possible extremes of distortion are enlarged.

Key words: constituencies, extremes of distortion, boundaries of the constituencies, relative majority. 